\title{
Pemetaan Kawasan Sentra Produksi bagi UMKM di Kota Ternate
}

\author{
Linda Umasugi ${ }^{1}$
}

\author{
${ }^{1}$ Universitas Muhammadiyah Maluku Utara, Indonesia
}

\author{
■ Info Artikel: \\ Diterima : 27 Mei 2018 \\ Disetujui : 13 Juni 2018 \\ Dipublikasi : 26 Juli 2018 \\ Artikel Penelitian \\ Dd Keyword: \\ Pemetaan, Kawasan dan Sentra Produksi \\ $\triangle$ Korespondensi: \\ Linda Umasugi \\ Universitas Muhammadiyah Maluku Utara, \\ Indonesia \\ Email: umasugi_linda@gmail.com

\section{(c) (i) (2)(2)} \\ Copyright@ Mei 2018 AGRIKAN
}

\begin{abstract}
Abstrak. Suatu wilayah/kawasan yang sukses dalam industrinya adalah yang mampu menciptakan dan mengembangkan faktor creation yang dibutuhkan sesui dengan potensinya, dan wilayah itu akan memiliki keunggulan daya saing dalam menciptakan faktor-faktor produksi yang terspesialisasi (specialized factor) dan sangat tergantung pada: (a) Kondisi permintaan lokal, (b) Keberadaan industri dan pendukung industri terkait, (c) Tujuan perusahaan dan karakteristik persaingan, Oleh karena itu Pemetaan Kawasan Sentra Produksi (P-KSP) merupakan salah satu bentuk pemetaan sentra produksi untuk sektor strategis yang diharapkan dapat mendorong percepatan peningkatan nilai tambah yang diikuti peningkatan produksi pada sentra-sentra produksi dari sub sektor pertanian tanaman pangan, subsektor perkebunan, subsektor kehutanan, subsektor perikanan dan subsektor peternakan yang didukung oleh sarana dan prasarana yang relevan. Tujuan pada penelitian ini adalah Mengidentifikasi komoditas unggulan dari setiap sub sektor untuk dikembangkan menjadi suatu Kawasan sentra produksi, Mengidentifikasi usaha mikro, kecil, dan menengah untuk dikembangkan menjadi sentra-sentra produksi, Melakukan pemetaan kawasan sentra produksi yang bermanfaat untuk pengembangan UKM di Provinsi Maluku Utara sebagai kegiatan usaha untuk peningkatan nilai tambah produk primer yang dihasilkan, Menganalisis daya dukung sumberdaya dalam pengembangan UMKM di Provinsi Maluku Utara, dan Menganalisis Strategi Pengembangan UMKM dengan mempertimbangkan aspek kekuatan, kelemahan, peluang dan ancaman.
\end{abstract}

\section{PENDAHULUAN}

\subsection{Latar Belakang}

Pembangunan ekonomi yang hanya mengejar pertumbuhan tinggi dengan mengandalkan keunggulan komparatif yang didasarkan pada: kekayaan alam yang berlimpah, upah tenaga kerja murah, dipertahankan lagi. Daya saing tidak dan posisi strategis, saat ini sulit untuk dapat diperoleh dari misalnya faktor upah rendah atau tingkat bunga rendah, tetapi harus pula diperoleh dari kemampuan untuk melakukan perbaikkan dan inovasi secara berkesinambungan. Porter (1990) mengatakan bahwa faktor keunggulan komparatif telah dikalahkan oleh keungulan kompetitif, dengan kemajuan teknologi.

Setiap kawasan unggulan masih mempunyai faktor keunggulan khusus yang bukan didasarkan pada biaya produksi yang murah saja, tetapi lebih dari itu, yaitu adanya inovasi (inovation). Sumberdaya alam yang dimiliki saat ini sudah tidak dapat diandalkan lagi karena sudah banyak terkuras. Oleh karena itu yang mengarah pada pembentukan keunggulan daya saing perlu digali dan tentunya setelah itu perlu dan harus diterapkan. Hirarki faktor produksi perlu dibuat untuk mengetahui peranan factor produksi didalam menciptakan keunggulan daya saing produk unggulan yang merupakan potensi suatu kawasan. Untuk menciptakan keungulan daya saing kawasan, maka jauh lebih baik dan lebih utama melalui mekanisme penciptaan faktor-faktor produksi dibandingkan dengan faktor-faktor yang diwariskan (business factor).

Suatu wilayah/kawasan yang sukses dalam industrinya adalah yang mampu menciptakan dan mengembangkan faktor creation yang dibutuhkan sesuai dengan potensinya, dan wilayah itu akan memiliki keunggulan daya saing dalam menciptakan faktor-faktor produksi yang terspesialisasi (specialized factor). Tidak ada satu wilayah yang dapat menciptakan dan mengembangkan semua tipe dan jenis faktor produksi, penentuan tipe dari faktor produksi yang akan diciptakan dan dikembangkan dan seberapa besar efektifitasnya sangat tergantung pada: (a) Kondisi permintaan lokal, (b) Keberadaan industri dan pendukung industri terkait, (c) Tujuan perusahaan dan karakteristik persaingan domestik, Oleh karena itu Pemetaan Kawasan Sentra Produksi (P-KSP) merupakan 
salah satu bentuk pemetaan sentra produksi untuk sektor strategis yang diharapkan dapat mendorong percepatan peningkatan nilai tambah yang diikuti peningkatan produksi pada sentra-sentra produksi dari sub sektor pertanian tanaman pangan, subsektor perkebunan, subsektor kehutanan, subsektor perikanan dan subsektor peternakan yang didukung oleh sarana dan prasarana yang relevan. untuk mempercepat pertumbuhan dan perkembangan di daerah, dipandang perlu adanya pemetaan Kawasan Sentra Produksi guna pengembangan usaha kecil, mikro, dan menengah yang dibentuk dalam suatu kawasan sebagai Sentra Pengembangan Produksi berskala kecil (mikro) dan ekonomis. Ini dilakukan untuk meningkatkan pertumbuhan ekonomi khususnya di suatu wilayah, serta pemerataan pembangunan ekonomi wilayah.

\subsection{Tujuan}

1. Mengidentifikasi komoditas unggulan dari setiap sub sector untuk dikembangkan menjadi suatu Kawasan sentra produksi.

2. Mengidentifikasi usaha mikro, kecil, dan menengah untuk dikembangkan menjadi sentra-sentra produksi.

3. Melakukan pemetaan kawasan sentra produksi yang bermanfaat untuk pengembangan UKM di Provinsi Maluku Utara sebagai kegiatan usaha untuk peningkatan nilai tambah produk primer yang dihasilkan.

4. Menganalisis daya dukung sumberdaya dalam pengembangan UMKM di Provinsi Maluku Utara.

5. Menganalisis Strategi Pengembangan UMKM dengan mempertimbangkan aspek kekuatan, kelemahan, peluang dan ancaman..

\section{PEMBAHASAN}

\subsection{Pengertian Sentra Produk Unggulan}

Dalam Surat Keputusan Menteri Negara Koperasi dan UKM No: 32/Kep/M.KUKM/IV/2002, tanggal 17 April 2002 tentang Pedoman Penumbuhan dan Pengembangan Sentra UKM, SENTRA didefinisikan sebagai pusat kegiatan di kawasan/lokasi tertentu dimana terdapat UKM yang menggunakan bahan baku/sarana yang sama, menghasilkan produk yang sama/sejenis serta memiliki prospek untuk dikembangkan menjadi klaster. Sentra merupakan unit kecil kwasan yang memilik ciri tertentu dimana didalamnya terdapat kegiatan proses produksi suatu jenis produk unggulan. Sentra merupakan area yang lebih khusus untuk suatu komoditi suatu kegiatan ekonomi yang telah membudaya yang ditunjang oleh pasarana dan sarana untuk

Berkembangnya produk atau jasa yang terdiri dari sekumpulan pengusaha mikro, kecil dan menengah. Diarea sentra produksi unggulan tersebut ada satu kesatuan fungsional secara fisik: lahan, geografis, agroklimat, infrastruktur, dan kelembagaan dan sumberdaya manusia, yang berpotensi untuk berkembangnya kegiatan ekonomi dibawah pengaruh pasar dari suatu produk yang mempunyai nilai jual dan daya saing tinggi. Sentra produk unggulan pada umumnya berkaitan dengan industri, oleh karena itu perlu batasan mengenai perindustrian.

\subsection{Pengertian Industri}

Industri adalah kegiatan ekonomi yang mengolah bahan mentah, bahan baku, barang setengah jadi dan atau barang jadi menjadibarang dengan nilai lebih tinggi untuk penggunaannya, termasuk kegiatan rancang bangun dan perekayasaan insdustri. Bidang usaha industri adalah lapangan kegiatan yang bersangkutan dengan cabang industri atau jenis industri.

Perusahaan industri adalah badan usaha yang melakukan kegiatan usaha di bidang usaha industri. Jasa industri adalah kegiatan usaha yang bersangkutan dengan jasa pelayanan, pemeliharaan, perbaikan dan penunjang industri lainnya. Kawasan industri adalah kawasan tempat pemusatan kegiatan industri pengolahan yang dilengkapi dengan prasarana dan fasilitas penunjang lainnya yang disediakan dan dikelola perusahaan kawasan industri, Izin usaha Kawasan Industri adalah izin yang diberikan kepada perusahaan kawasan industri untuk melakukan kegiatan pengembangan dan pengeloaan kawasan industri, Perusahaan Kawasan Industri adalah perusahaan yang merupakan badan hukum yang didirikan menurut hukum Indonesia dan berkedudukan di Indonesia yang mengelola kawasan industri. Industri sentra, yaitu kelompok industri yang dari segi satuan usaha mempunyai skala kecil tetapi membentuk suatu pengelompokan atau kawasan produksi yang terdiri dari kumpulan usaha yang sejenis. Dari segi pemasarannya kelompok ini umumnya menjangkau pasar yang lebih luas dan peran pedagang perantara/pedagang pengumpul menjadi cukup menonjol.

\subsection{Definisi Usaha Kecil dan Menengah \\ Departemen Perindustrian RI pada tahun} 1991 mendefinisikan industry kecil dan kerajinan 
adalah kelompok perusahaan yang dimiliki penduduk Indonesia dengan jumlah nilai aset kurang dari Rp. 600 juta diluar nilai tanah dan bangunan yang digunakannya. Mengacu pada Undang-Undang Nomor 9 Tahun 1995, kriteria usaha kecil adalah:

1. Memiliki kekayaan bersih paling banyak Rp. 200 juta (tidak termasuk tanah dan bangunan tempat usaha), atau

2. Memiliki hasil penjualan paling banyak Rp. 1 miliar/tahun.

3. Dimiliki oleh Warga Negara Indonesia.

4. Berdiri sendiri bukan merupakan anak perusahaan atau cabang perusahaan yang dimiliki, dikuasai atau berafiliasi baik langsung, maupun tidak lengsung dengan usaha menengah atau besar; dan

5. Terbentuk usaha orang perseorangan, badan usaha yang tidak berbadan hukum, atau badan usaha yang berbadan hukum termasuk koperasi.

Sedangkan untuk kriteria usaha menengah menurut UU. No. 9 Tahun 1995 adalah:

1. Untuk sektor industri, memiliki total aset paling banyak Rp. 5 miliar, dan

2. Untuk sektor non industri, memiliki kekayaan bersih paling banyak Rp. 600 juta tidak termasuk tanah dan bangunan tempat usaha; memiliki hasil penjualan tahunan paling banyak Rp. 3 miliar.

Bank Indonesia mengacu pada definisi yang sesuai dengan UU No. 9 tahun 1995 karena kriteria usaha kecil dan menengah dalam Peraturan Bank Indonesia yang berkaitan dengan pemberian Kredit Usaha Kecil (PBI No. 3/2/PBI/2001) merujuk pada UU tersebut. Menurut Inpres No. 10 tahun 1999, usaha menengah sebagai unit kegiatan yang memiliki kekayaan bersih lebih besar dari Rp. 200 juta sampai maksimal Rp. 10 miliar (tidak termasuk tanah dan bangunan tempat usaha), milik Warga Negara Indonesia, berdiri sendiri dan bukan merupakan anak perusahaan atau cabang perusahaan yang dimiliki, dikuasai atau berafiliasi baik langsung maupun tidak langsung dengan usaha besar. Instansi lain seperti Depperindag juga mengeluarkan ketentuan mengenai industri skala kecil menengah yang dituangkan dalam Keputusan Menperindag (Kepmenperindag) No. 257/MPP/Kep/7/1997. Definisi UKM dalam Kepmenperindag adalah suatu usaha dengan nilai investasi maksimal Rp. 5 miliar termasuk tanah dan bangunan. Sedangkan BPS membagi jenis UKM berdasarkan jumlah tenaga kerja, yaitu:
1. Kerajinan rumah tangga, dengan jumlah tenaga kerja dibawah 3 orang termasuk tenaga kerja yang tidak dibayar

2. Usaha Kecil, dengan jumlah tenaga kerja sebanyak 5 - 9 orang

3. Usaha menengah, dengan jumlah tenaga kerja sebanyak $20-99$ orang.

Definisi UKM pada tingkat internasional dikeluarkan oleh World Bank yang membagi UKM ke dalam 3 jenis, yaitu:

1. Medium enterprise, dengan kriteria:

I. Jumlah karyawan maksimal 300 orang

II. Pendapatan setahun hingga sejumlah \$ 15 juta, dan

III. Jumlah aset hingga sejumlah $\$ 15$ juta

2. Small enterprise, dengan kriteria:

I. Jumlah karyawan kurang dari $\mathbf{3 0}$ orang

II. Pendapatan setahun tidak melebihi \$ 3 juta, dan

III. Jumlah aset tidak melebihi $\$ 3$ juta

3. Micro Commision, dengan kriteria:

I. Jumlah karyawan kurang dari 10 orang

II. Pendapatan setahun tidak melebihi \$ 100 ribu, dan

III. Jumlah aset tidak melebihi \$ 100 ribu

\subsection{Potensi Dan Sentra Produk Unggulan UMKM Di Kota Ternate}

Sentra didefinisikan sebagai pusat kegiatan di kawasan/lokasi tertentu dimana terdapat UKM yang menggunakan bahan baku/sarana yang sama, menghasilkan produk yang sama/sejenis serta memiliki prospek untuk dikembangkan menjadi klaster. Sentra merupakan area yang lebih khusus untuk suatu komoditi suatu kegiatan ekonomi yang telah membudaya yang ditunjang oleh prasarana dan sarana untuk berkembangnya produk atau jasa yang terdiri dari sekumpulan pengusaha mikro, kecil, dan menengah.

Kepentingan pemetaan kawasan sentra produksi bagi pengembangan UMKM di Provinsi Maluku Utara, setelah melalui tahapan pengumpulan data dan analisis maka telah teridentifikasi potensi dan sentra usaha mikro kecil dan menengah di Kota Ternate. Sentra produksi unggulan merupakan satu kesatuan fungsional secara fisik: lahan, geografis, agroklimat, infrastruktur, serta kelembagaan dan sumberdaya manusia, yang berpotensi untuk berkembangnya kegiatan ekonomi dibawah pengaruh pasar dari suatu produk yang mempunyai nilai jual dan daya saing.

1. Potensi dan Sentra Produksi UMKM di Kota Ternate 
Kota Ternate dalam aktifitas perekonomiannya berdasarkan beberapa analisis dan perkembangannya merupakan suatu wilayah yang didominasi oleh peranan sektor sekunder dan tersier. Perkembangan industri di Kota Ternate cukup pesat terutama yang berskala kecil dan menengah. Industri yang berkembang di Kota Ternate adalah jenis industri kecil dan rumah tangga. Jenis industri ini cukup banyak di wilayah ini karena penggunaan teknologi yang relative sederhana dan keterbatasan aspek permodalan. Meskipun jenis industri yang ada sebagian besar berskala kecil tapi cukup mampu menyerap tenaga kerja sehingga dapat mengurangi angka pengangguran di Kota Ternate.
Jenis industri yang berkembang di Kota Ternate adalah industri di bidang pangan, industri di bidang kimia dan bahan bangunan, industri bidang sandang, kulit dan kerajinan umum, serta industri bidang logam. Dari keempat bidang usaha industri tersebut, industri yang memiliki nilai investasi tinggi dan memiliki kemampuan penciptaan kesempatan kerja yang baik adalah industri bidang kimia dan bahan bangunan serta industri bidang pangan. Secara kewilayahan kecamatan, perkembangan UMKM di Kota Ternate sangat pesat. Kecamatan yang sangat intens pertumbuhan UMKM adalah berada pada wilayah Kecamatan Ternate Utara sebanyak 3120 usaha dan Kecamatan Ternate Selatan sebanyak 2466 usaha (lihat Tabel 1).

Tabel 1. Perkembangan UMKM Per Kecamatan di Kota Ternate

\begin{tabular}{llcc}
\multicolumn{1}{c}{ Kecamatan } & 2014 & 2015 \\
\hline 1 & Ternate Utara & 2706 & 3120 \\
2 & Ternate Tengah & 1302 & 1302 \\
3 & Ternate Selatan & 2197 & 2466 \\
4 & Pulau Ternate & 229 & 603 \\
5 & Kota Moti & 308 & 308 \\
6 & Pulau Batang dua & 81 & 189 \\
7 & Pulau Hiri & 294 & 294 \\
\hline \multicolumn{2}{l}{ Sumber: Dinas Perindustrian dan Perdagangan Kota Ternate } \\
\hline
\end{tabular}

Secara terperinci, empat bidang industri berskala mikro kecil dan menengah yang tumbuh di Kota Ternate dapat dilihat pada Tabel 5, 6, 7, dan 8 . Industri skala mikro kecil dan menengah bidang pangan yang tumbuh pesat di Kota Ternate adalah usaha roti, usaha pengasapan ikan dan usaha minuman ringan. Sedangkan dilihat dari daya serap tenaga kerja per unit usaha, terdapat tiga jenis usaha yang berdaya serap tenaga kerja tinggi yaitu usaha es balok, usaha tahu tempe, dan usaha minuman sari buah.

Tabel 3. Potensi Industri Mikro di Kota Ternate

\begin{tabular}{llccc}
\hline NO & Jenis Industri Skala UMKM & $\begin{array}{c}\text { Jumlah Usaha } \\
\text { (Unit) }\end{array}$ & $\begin{array}{c}\text { Jumlah } \\
\text { Tenaga Kerja } \\
\text { (Orang) }\end{array}$ & Nilai Investasi (Rp) \\
\hline Pengasapan Ikan & 6 & 13 & 20.385 .000 \\
Mi Kering & 2 & 5 & 30.850 .000 \\
Roti & 13 & 32 & 116.110 .000 \\
Es Balok & 1 & 12 & 1.500 .000 \\
Tahu/Tempe & 3 & 24 & 41.050 .000 \\
Minuman Sari Buah & 1 & 8 & 1.400 .000 \\
Minuman Ringan & 6 & 12 & 143.765 .000 \\
Cuka Makan & 1 & 2 & 380.000 \\
Pati Ubi Kayu & 3 & 13 & 11.169 .000 \\
Kripik Singkong dan Tapioka & 2 & 7 & 2.790 .000 \\
Abon Ikan & 2 & 5 & 2.800 .000 \\
Lain-lain & 3 & 7 & 31.550 .000 \\
\hline
\end{tabular}

Sumber: Dinas Perindustrian dan Perdagangan Kota Ternate, Tahun 2014

2.5. Kondisi Dan Daya Dukung Sumberdaya

Dalam Pengembangan Sentra Produksi Umkm di Kota Ternate
Keberhasilan Usaha Mikro, Kecil dan Menengah (UMKM) memiliki korelasi dengan beberapa komponen pendukung. Komponen 
tersebut adalah: (1) Sumber Daya Manusia (SDM); (2) Ketersediaan energi listrik; (3) Ketersediaan Air Bersih; (4) Keberadaan perbankan.

\section{Daya Dukung Sumber Daya Manusia}

Karekteristik dari UMKM salah satunya adalah jumlah tenaga kerja yang berlimpah. Faktor yang membuat keadaan itu terjadi, karena manusia yang bekerja pada sektor ini memiliki strata pendidikan yang cukup rendah. Pendidikan pada strata Sekolah Dasar (SD) yang banyak mendominasi pekerja pada sektor ini. Sumberdaya manusia memiliki andil besar untuk kemajuan UMKM. SDM merupakan salah satu penilaian internal untuk melihat kelemahan (weaknes) dan kekuatan (strength) pada sebuah entitas bisnis. Pengelola UMKM yang memiliki pegetahuan dan pengalaman akan memberikan nilai tambah berupa pengembangan produk dan pengembangan usaha, mampu mengikuti perubahan dengan melakukan inovasi untuk beradaptasi di tengah persaingan usaha yang kompetitif. UMKM yang memiliki SDM seperti ini, berpeluang lebih besar untuk menjadi UMKM yang andal. Karena orientasinya tidak sekadar untuk memenuhi kehidupan ekonomi jangka pendek semata atau sebagai usaha sampingan. Melainkan menjadikan usaha tersebut sebagai aktivitas ekonomi jangka panjang. Usaha yang menghasilkan produk dengan teknik yang efisien dan efektif. Produk yang dihasilkannya berdaya saing, dapat memasuki wilayah pemasaran di daerah lain.

Karakteristik SDM pada UMKM secara umum adalah memiliki kuantitas yang sangat melimpah, namun belum sebanding dengan pemilikan kualitas. SDM yang berada di UMKM memiliki keterbatasan pengetahuan dan pengalaman. Karena pelaku usaha menggunakan pendekatan konvensional dan cenderung jangka pendek, maka perhatian terhadap SDM relatif belum maksimal. Melimpahnya SDM yang dimiliki UMKM membawa dampak pada reward berupa gaji atau upah yang diterima oleh tenaga kerja yang berada di UMKM masih rendah, belum memenuhi standar gaji yang berlaku sesuai ketetapan pemerintah setempat. Hal ini membuat tingkat employment turn over relatif tinggi, yaitu karyawan masuk dan keluar dari sebuah usaha cukup tinggi.
2. Daya Dukung Kapasitas Energi Listrik

Pada konteks penilaian kemampuan usaha, komponen pendukung seperti energi listrik termasuk kategori penilaian eksternal. Penilaian ini berkaitan dengan kesempatan (opportunities) dan ancaman (threath). Kesempatan karena dukungan eksternal dapat memberikan konstribusi positif bagi sumber daya bisnis UMKM. Sedangkan ancaman merupakan dampak sebaliknya, dapat berpengaruh negatif bagi perkembangan UMKM. Ketersediaan energi listrik di suatu wilayah Kota Ternate adalah bagian dari kemampuan pemerintahan untuk merencanakan dan merealisasikanny.

Energi listrik mempunyai dukungan penting dalam keberhasilan UMKM. Energi sebagai pembangkit alat-alat produksi untuk mengelola produk (barang dan jasa) hingga dapat dikonsumsi oleh konsumen. Ketersediaan energi akan menciptakan optimalisasi kinerja UMKM, menghasilkan produk yang lebih murah, tepat waktu, dan daya saing sehingga produk yang dihasilkan sesuai dengan rencana kapasitas produksi.

3. Daya Dukung Kapasitas Air Bersih

Faktor pendukung lainnya yang penting dalam pengembangan UMKM adalah ketersediaan air bersih. Berdasarkan peraturan Menteri Kesehatan No. 907/Menkes/SK/VII/2002 mensyaratkan standar air bersih dan pengawasan kualitas air minum. Tujuan peraturan ini adalah menetapkan standar kualitas air untuk meningkatkan derajat kesehatan masyarakat. Bertambahnya jumlah penduduk, maka semakin besar kebutuhan konsumsi air bersih. Demikian juga dengan peningkatan ekonomi daerah membawa pengaruh terhadap peningkatan konsumsi air. Untuk memenuhi ketersediaan air bersih, selain menggunakan sarana non-perpipaan (misal, sumur atau pompa yang dibuat masyarakat) juga memerlukan sarana perpipaan yang dikelola oleh Perusahaan Daerah Air Minum (PDAM). Sarana pertama (non-perpipaan) cukup terbatas, mengingat tidak semua daerah dapat memenuhi air bersih dengan cara tersebut, selain struktur tanah yang sulit juga tempat pemukiman yang tidak layak untuk menggunakan sarana tersebut. Umumnya di Kota Ternate menggunakan sarana kedua (perpipaan).

Ketersediaan air bersih menjadi sangat penting untuk menjaga kelangsungan mahluk hidup. Bagi manusia air bersih menjadi kebutuhan 
utama. Begitu pun dengan UMKM, bukan saja jumlah ketersediaan air, tetapi ketersediaan air yang berkualitas Di beberapa daerah Di Kota Ternate. Faktor pendukung ini termasuk dalam kategori penilaian eksternal. Sebab UMKM tidak mampu menyediakan atau memilikinya. Cost untuk menyediakan sangat besar, karena itu membutuhkan perhatian pemerintah daerah untuk menyediakan dan meningkatkan pemenuhan air bersih. Dua hal penting yang harus diperhatikan oleh pemerintah adalah kuantitas dan kualitas air bersih. Perhatian kuantitas air yaitu dengan merencanakan sumber air melalui sumur dan sungai dengan sistem gravitasi atau pompa, mengairi melalui pemasangan pipa, perluasan jangkauan air bersih untu memenuhi kebutuhan masyarakat, dan memiliki program pemeliharaan sumber air. Sedangkan perhatian pada kualitas air yaitu, pemerintah Kota harus memiliki standar kualitas baku air dan kriteria perencanaan pen yediaan air bersih.

4. Daya Dukung Perbankan

Bank sebagai lembaga intermediasi keuangan, berfungsi menghimpun dana yang berasal dari masyarakat dan mendistribusikan kepada masyarakat dalam entuk kredit atau pembiayaan untuk meningkatkan kesejahteraan masyarakat. Fungsi lainya adalah menyediakan jasa transaksi pembayaran baik tunai dan nontunai. Beberapa jasa lainnya yang disediakan bank untuk mempermudah dan memberikan keamanan kepada masyarakat. Dari pengertian itu, dapat dinyatakan bahwa indikasi kemajuan ekonomi dapat dilihat dari banyaknya jumlah bank di suatu daerah. Semakin besar transaksi ekonomi akan memberikan efek kepada arus uang (lalu-lintas uang), maka industri perbankan akan memilih daerah yang transaksi ekonominya besar, dengan menempatkan cabang atau membuka bank (BPR atau BPRS). Kontribusi signifikan besarnya transaksi ekonomi adalah berasal dari UMKM. Meskipun demikian, ketidakcukupan modal usaha. Untuk masalah klasik UMKM masih seputar itu dengan keberadaan bank di Kota Ternate akan membantu kesulitan permodalan yang dialami UMKM.

\section{PENUTUP}

Perkembangan industri di Kota Ternate cukup pesat terutama yang berskala kecil dan menengah. Jenis Industri yang berkembang beraneka ragam dimulai dari jenis industri kecil dan rumah tangga. Keberhasilan Usaha Mikro, Kecil dan Menengah (UMKM) memiliki korelasi dengan beberapa komponen pendukung seperti adanya sumber daya lahan dan wilayah dan sumber daya manusia, serta didukung oleh pembiayaan sehingga, pemetaan kawasan sentra produksi untuk pengembangan UKM di Kota Ternate akan membawa dampak bagi penghasil bahan baku di daerah lain bagi UKM di Kota Ternate akan berjalan sinergi. Namun hal tersebut jika tidak ditunjang oleh campur tangan pemerintah daerah sebagai bagian pemangku kebijakan pembangunan daerah maka, hal tersebut diatas tidak akan terlealisasi, bahkan target dalam pengembangan UKM akan tersendat bahkan stag di tempat.

\section{REFERENSI}

2012. Kota Ternate Dalam Angka 2012 . BPS Kota Ternate. Ternate.

BPS Provinsi Maluku Utara. 2013. Provinsi Maluku Utara. Ternate

Brata, A.G. 2003. Distribusi spasial Ekonomi Rakyat, UKM di masa krisis ekonomi, Jurnal Tahun II,No.8,

Nopember, http://www.ekonomirakyat.org/edisi_20/

David, F. R. 2002. Manajemen Strategis. Alih bahasa Alexander Sindoro. PT. Prenhallindo, Jakarta

Disperindag Kota Ternate. 201 2. Direktor, Potensi, dan Sentra Produksi Industri Kecil dan Menengah

Tahun 2012 . Disperindag Kota Ternate. Ternate

Gandaniati, Nur Mira Strategi Pengembangan Usaha Kecil Menengah Kerajinan Dengan Pendekatan Penelitian Aksi Partisipatif (Studi Kasus Ukm Ozi Aircraft Model, Desa Cikarawang Kabupaten Bogor).

Kuncoro, M. 2002a, Analisis spasial dan regional: Studi aglomerasi dan kluster industri Indonesia, Yogyakarta: UPP AMP YKPN

Murphy, D. 2000, Membangun organisasi rakyat, URM-Indonesia, Jakarta.

Nasution, A. 2003, Strategi pembangunan ekonomi baru, Makalah Dipresentasikan pada Kongres ISEI XV di Malang, 13-15 Juli 2003. 